\title{
The influence of invasive Fallopia taxa on resident plant species in two river valleys (southern Poland)
}

\author{
Damian Chmura1*, Barbara Tokarska-Guzik², Teresa Nowak², Gabriela Woźniak³, Katarzyna Bzdęga², \\ Katarzyna Koszela², Małgorzata Gancarek² \\ 'Institute of Environmental Protection and Engineering, Faculty of Materials and Environmental Sciences, University of Bielsko-Biala, Willowa 2, 43-309 Bielsko-Biala, Poland \\ 2 Department of Plant Systematics, University of Silesia, Jagiellońska 28, 40-032 Katowice, Poland \\ ${ }^{3}$ Department of Geobotany and Nature Protection, University of Silesia, Jagiellońska 28, 40-032 Katowice, Poland
}

\section{Abstract}

Riparian zones in two rivers in southern Poland were studied in terms of species composition and soil parameters in patches dominated by three knotweed taxa (Fallopia japonica, F. sachalinensis and the hybrid F. $\times$ bohemica). The main purpose was to detect any differences in species diversity, environmental conditions and in the impact of the three Fallopia spp. on resident species. Fieldwork was conducted in spring and summer in 30 invaded plots (in total 90 subplots). It was demonstrated that vegetation dominated by particular knotweed taxa differed in response to soil $\mathrm{pH}$ and ammonium, nitrate, and magnesium content. Fallopia spp. (living plants and necromass) had a stronger negative impact on the cover and species diversity of the resident species in summer in comparison with spring. Vegetation patches differed significantly in species composition in relation to the knotweed taxa present. These differences may be the consequence of the differentiated biotopic requirements of Fallopia taxa and the coexisting plants, or to the different impact of the knotweed taxa on the resident species.

Keywords: biological invasions; Reynoutria taxa; riverside vegetation; phenology

\section{Introduction}

Species diversity remains one of the significant criteria investigated in contemporary ecology, being considered a suitable measure of the quality of the environment ([1] and the literature cited therein). At the same time invasion by alien species has been recognized as one of the major threats to natural biodiversity [2], although individual habitats vary considerably in their susceptibility to invasion [3].

Riparian woodlands are communities with high species richness, identified as habitats with especial nature conservation value (e.g. [4,5]). These particular habitats, together with other waterside situations, are the most endangered by and most easily invaded by alien invasive plants [6,7], and then play a role of transmission into other more typically terrestrial habitats, such as dry scrub and woodland. This fact has an important role in planning management for river banks and river valleys.

Among the world's most invasive vascular plants are the representatives of the genus Fallopia (syn. Reynoutria; Polygonaceae): F. japonica (Houtt.) Ronse Decraense,

\footnotetext{
* Corresponding author. Email: dchmura@ath.bielsko.p
}

Handling Editor: Zygmunt Dajdok
F. sachalinensis (F.W. Schmidt ex Maxim.) Nakai, and the hybrid F. ×bohemica (Chrtek and Chrtková) J. Bailey (e.g. [8]). This Fallopia species complex, sometimes referred to as Japanese knotweed sensu lato, penetrates both into plant communities transformed by humans, and into natural communities, including those of alluvial plains (e.g. [9-14]), and the taxa are simultaneously a remarkable example of transformer species [15].

Fallopia taxa are among the tallest polycarpic perennial plants. They have aerial annual stems up to 3-4 meters high, and are able to form very dense monospecific patches $[12,16]$. Their rhizome system is very dense and can grow to 2 meters in depth [17]. Recent studies have shown that, apart from extensive vegetative growth, hybridization between the F. japonica and F. sachalinensis has created even more highly invasive genotypes of the hybrid F. $\times$ bohemica that are able to establish themselves by seed $[15,18,19]$.

The stand-forming habit of these species produces a dense summer canopy beneath which few other species can survive due to competition for light [14,20,21]. In addition, their rhizome system grows rampantly, producing stem litter, and the plants intensively remove nutrients from the soil, thus also taking over ground from their competitors $([12,22,23]$ and the literature cited therein). The same authors 
conclude that Fallopia taxa (F. japonica) may contribute to soil homogenization in invaded landscapes.

All these factors, together with changes in the abiotic or biotic environment in Fallopia populations, may also affect the germination and survival of seedlings or juvenile plants of native species, and thus prevent their colonization and recruitment [24]. Other authors point out that allelopathy may play a role in the impact of Fallopia invasion on the species diversity of invaded communities [14,25].

Invasion success in alien species is dependent on a set of many plant traits which make it more invasive. Differences in the biology of the studied Fallopia taxa may result in differences in the way they affect the riparian vegetation patches in which they occur [26]. In the riparian habitats the participation of F. japonica, F. sachalinensis and their hybrid $F$. $\times$ bohemica varies in the number and abundance of the different taxa [20].

Previous studies confirming the possibility of the sexual reproduction (also, indirectly, through the genetic variability found in F. $\times$ bohemica), showed that the Fallopia species differ in their ecology, establishment success [27,28], response to control measures [28], genetic variation [29], and their effect on the germination and establishment of species in invaded stands [14]. A few previous studies suggested that three Fallopia taxa differed in their competitive ability. Hybrid F. $\times$ bohemica was proven to spread faster, and this is also possibly due to its genetic diversity. A study using experimental communities of native plants and Fallopia taxa revealed that the hybrid performed significantly better than the parental species [30]. Some studies on other species showed that hybrids can be more plastic and more tolerant to environmental conditions [31].

Even though the invasion by Fallopia taxa is among the most intensively studied phenomena globally [14,32,33], nevertheless new aspects should be paid attention to and need explanation. More rarely undertaken studies, determining the influence of Fallopia taxa on abiotic and biotic conditions of particular habitats, devote attention to individual taxa from the Fallopia genus. One example of such a study, although limited to laboratory conditions, was the experiment designed by Moravcová et al. [14], showing that Fallopia above-ground plant parts could potentially inhibit the germination of other plant species, and that the effect differs among the three taxa of the genus.

Records of Fallopia taxa occurring in riparian vegetation patches are numerous, but the exact influence of soil properties on their presence, and the impact of knotweeds on the species composition of invaded sites have not been studied in detail. Previous studies have revealed that all three Fallopia congeners separately exhibit a negative impact on species richness and species composition in sites which they invade [34]. A few studies (e.g. [19]) analyzed the species composition of sites invaded by Fallopia but by using phytosociological relevés, without environmental measurements and on a small number of plots.

One of the most important aspects of the project presented here is to assess the effect of particular Fallopia taxon on species diversity. We seek to determine which soil parameters affect the species composition of vegetation patches dominated by Fallopia taxa. We are interested in how strong, and if any, is the negative impact of cover of particular Fallopia taxa on species diversity, and how it varies during the vegetation season. We would like to know whether there are differences among Fallopia taxa regarding this aspect in terms of season and the whole year. The other important issue is the influence of the necromass forming due to the decomposition of fallen leaves from Fallopia plants. The role of the cover of mosses and its relation with vascular plants including Fallopia taxa is also highlighted.

Based on the aforementioned questions the following hypotheses were formulated with the intention of falsifying them:

(i) The patches of riparian vegetation dominated by Fallopia spp. do not differentiate equally along environmental gradients. We expected that $F$. $\times$ bohemica patches would show the highest variation and $F$. $s a$ chalinensis show the lowest.

(ii) There are no differences in the biotopic requirements of Fallopia patches between spring and summer.

(iii) The cover of Fallopia taxa in summer is higher than in spring, whereas the total cover of resident species, both vascular and moss species, is lower due to the impact of knotweeds.

(iv) The species diversity of native plants under the canopy of Fallopia spp., measured by various biodiversity indices, decreases during the vegetation season what is mainly caused by phenology but can be modified by impact of knotweeds.

\section{Material and methods}

\section{Data collection}

For the purposes of the present study data were collected from riparian vegetation patches invaded by the three Fallopia taxa, occurring along two river valleys in southern Poland: the valleys of the Biała and Jasienica rivers (Fig. 1a). Along the rivers examined, vegetation consists of a mosaic of long-established semi-natural communities and intermediate to highly disturbed sites surrounded by agricultural fields. Permanent plots were set up in riparian vegetation patches in which the taxa studied: F. japonica, F. $\times$ bohemica and F. sachalinensis had become the dominants in the herb layer.

In total, 30 invaded plots (90 subplots) were set up in riparian communities along the two aforementioned river valleys (15 plots in each valley) as presented in the scheme (Fig. 1b). The plots were selected according to the following criteria: $(\boldsymbol{i})$ the site was heavily invaded by the objective Fallopia taxa individuals, with its populations as spatially homogeneous as possible, (ii) the invaded sites were adjacent to uninvaded riparian vegetation, (iii) the sites invaded by the three studied Fallopia taxa were as close as possible to get habitat conditions as unified as possible.

The experimental plots were established with the following design: (i) homogeneous F. japonica populations in five replicates along the Jasienica, and ten replicates along the Biała river; (ii) five plots with $F$. $\times$ bohemica along the Jasienica and five along the Biała river; (iii) five plots with F. sachalinensis but only in the Jasienica river valley because along the Biała river F. sachalinensis patches were absent. 


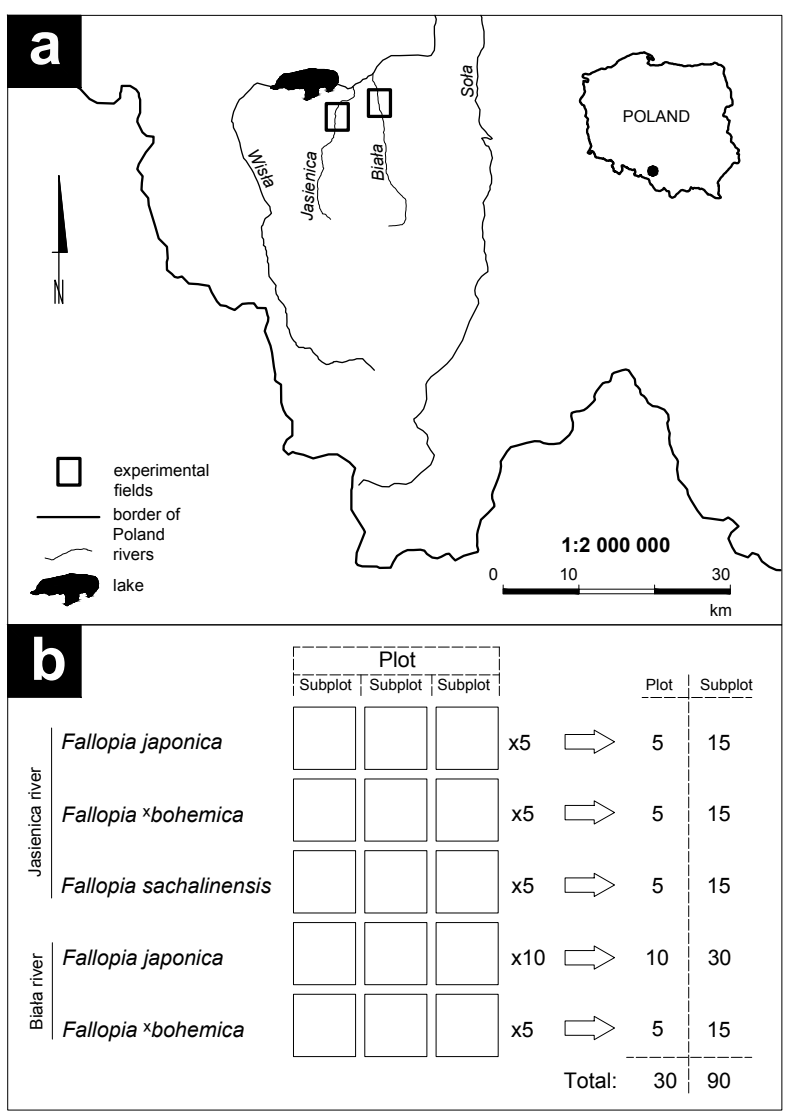

Fig. 1 Situation of the study area and sampling design.

Each plot $(10 \times 4 \mathrm{~m})$ was divided into three smaller subplots of $2 \times 2 \mathrm{~m}$ with a distance of 1 meter and 1 meter of border. For each subplot the cover of above-ground parts of all vascular plants present was recorded using 1,2,5\% and further $10 \%$ intervals. The cover of the moss layer and the cover of decaying biomass (litterfall), referred to here as necromass, were also estimated. These field measurements were made in late April (spring) and at the beginning of July (summer). No uninvaded sites were subjected to these studies.

Data on site abiotic conditions were collected in the same subplots (Tab. 1). In each subplot five soil cores $(0-10 \mathrm{~cm}$ depth, litter discarded) were taken with a soil borer $(4 \mathrm{~cm}$ in diameter) - one core was sampled at each corner of the square and one core at the center of the square. These five cores were mixed into a single bulk sample for each plot. Soil samples were air-dried to a constant weight and sieved $(<2 \mathrm{~mm})$. The following parameters were assessed on each sample: soil $\mathrm{pH}$, extractable potassium, available magnesium (the Schatschabel method), total phosphorus and total carbon (the calorimetric and the Tiurin method, respectively), the extractable ammonium nitrogen $\mathrm{N}-\mathrm{NH}_{4}$ and total nitrate nitrogen content.

\section{Statistical analysis}

In order to examine which species are significantly associated with, i.e. they can be interpreted as species best adopted or survived in vegetation patches invaded by knotweeds, one or two of the three Fallopia taxa studied, the IndVal (indicator value analysis) method was applied. The IndVal quantifies the fidelity and specificity of species in relation to groups of sites in a user-specified classification of sites and tests for the statistical significance of the associations ([35] and literature cited therein). Vegetation patches dominated by knotweeds except for $F$. sachalinensis were present in both river valleys so there was a high possibility of finding the same native plant species in each already mentioned plot. The classification of co-occurring species into three groups of sites - invaded by particular Fallopia taxa - at the scale of subplot and in a further step in the combination of the two groups of sites was performed. The statistical significance of this relationship was tested using a test with 999 permutations.

On the basis of plants present the following biodiversity indices were calculated: Shannon-Wiener index $H^{\prime}$, Simpson diversity index $D^{\prime}$, evenness $E$ and species richness $S$. The presence and cover of Fallopia taxa were excluded from the calculations. The Wilcoxon paired test was employed to assess the significance of changes between spring and summer in the cover of Fallopia taxa, total cover of vascular plants, cover of the moss layer, and mean values of biodiversity indices. To examine the relationships between biodiversity indices and total cover of Fallopia taxa, the Spearman rank correlation was made for two parts (spring and summer) of the growing season separately. Furthermore, data from spring and summer was combined in another analysis. For the same plots maximum cover of all plants present in subplots were compared. The canonical correspondence analysis (CCA) method with a matrix of soil parameters and species cover including knotweeds was used to show how patches with Fallopia taxa are distributed along environmental gradients. To study how the cover of particular taxa of the Fallopia genus, as well as necromass and moss cover, affect the species composition of the vascular flora of riparian habitats, CCA was also carried out. In both cases the CCA method was conducted with log transformation of data and with the Monte Carlo test (999 permutations) using CANOCO software (http://www.microcomputerpower.com). The CCAs were performed separately for spring and summer. Other statistical tests were performed using R software (http:// www.r-project.org).

Tab. 1 Descriptive statistics (median \pm interquartile range) of soil parameters of the river valleys of the Biała and the Jasienica.

\begin{tabular}{lcc} 
Parameter & Biała & Jasienica \\
\hline $\mathrm{pH}$ & $6.53 \pm 1.6$ & $6.51 \pm 1.3$ \\
Total $\mathrm{P}_{2} \mathrm{O}_{5}\left({\left.\mathrm{mg} 100 \mathrm{~g}^{-1}\right)}\right.$ & $14.0 \pm 5.8^{\star * *}$ & $6.5 \pm 6.0$ \\
Extractable $\mathrm{K}_{2} \mathrm{O}\left({\left.\mathrm{mg} 100 \mathrm{~g}^{-1}\right)}\right.$ & $16.9 \pm 18.2$ & $22.5 \pm 15.6$ \\
Available $\mathrm{Mg}\left({\left.\mathrm{mg} 100 \mathrm{~g}^{-1}\right)}^{\text {Total C org }(\%)}\right.$ & $11.4 \pm 10.9$ & $9.7 \pm 5.6$ \\
$\mathrm{~N}-\mathrm{NO}_{3}(\mathrm{mg} / \mathrm{kg}$ dry mass $)$ & $2.5 \pm 1.7$ & $2.2 \pm 0.7$ \\
$\mathrm{~N}_{-} \mathrm{NH}_{4}(\mathrm{mg} / \mathrm{kg}$ dry mass $)$ & $3.95 \pm 2.09$ & $5.43 \pm 5.79$ \\
\hline
\end{tabular}

${ }^{* * *} P<0.001$. 


\section{Results}

Both river valleys were similar in terms of chemical parameters except for soil phosphorus content, which was higher along the Biała river, and concentrations of ammonium ions which were higher along the Jasienica river (Tab. 1).

In spring, $\mathrm{pH}$, magnesium, and nitrogen (nitrates, ammonium ions) significantly explained influenced the species composition of patches with Fallopia taxa (Tab. 2). The vegetation patches with $F$. japonica were largely confined to higher $\mathrm{pH}$, patches with $\mathrm{F}$. $\times$ bohemica to higher contents of magnesium and potassium, whereas patches with F. achalinensis were characterized by a higher content of nitrogen (Fig. 2). In summer the situation was very similar. However, organic carbon started to play a more significant role for some sites with $F$. $\times$ bohemica (Tab. 2, Fig. 3). Both analyses demonstrated that vegetation patches dominated by F. japonica and F. $\times$ bohemica overlap more than those of F. sachalinensis in spring, whereas in summer all three types of plots differed significantly in terms of relationships with to soil variables. The Kruskal-Wallis test, followed by Conover test, revealed significant difference in the mean values of plot coordinates along the first two axes of CCA constrained by the used environmental variables in spring (Axis $1, \chi^{2}=25.4$, $P<0.0001$; Axis $2, \chi^{2}=10.7, P<0.004$ ) and summer (Axis 1, $\chi^{2}=32.4 ; P<0.0001$; Axis $\left.2, \chi^{2}=39.7, P<0.001\right)$.

Tab. 2 The results of the Monte Carlo test ( $P$-values) in CCA with soil parameters as constraining variables.

\begin{tabular}{lcc}
\hline Parameter & Spring & Summer \\
\hline $\mathrm{Mg}$ & $\mathbf{0 . 0 0 1}$ & $\mathbf{0 . 0 0 1}$ \\
$\mathrm{pH}(\mathrm{KCl})$ & $\mathbf{0 . 0 0 2}$ & $\mathbf{0 . 0 0 1}$ \\
Ammonium $\left(\mathrm{N}-\mathrm{NH}_{4}\right)$ & $\mathbf{0 . 0 3 5}$ & $\mathbf{0 . 0 0 1}$ \\
Nitrate $\left(\mathrm{N}-\mathrm{NO}_{3}\right)$ & $\mathbf{0 . 0 0 8}$ & $\mathbf{0 . 0 3 2}$ \\
$\mathrm{K}\left(\mathrm{K}_{2} \mathrm{O}\right)$ & 0.098 & 0.278 \\
$\mathrm{C}$ org & 0.351 & $\mathbf{0 . 0 3 5}$ \\
$\mathrm{P}\left(\mathrm{P}_{2} \mathrm{O}_{5}\right)$ & 0.303 & 0.062 \\
\hline
\end{tabular}

Bold values are significant at $P<0.05$.

Analysis of the abundance of plants during the two seasons demonstrated that in summer the total cover of Fallopia taxa was ca. tenfold higher, whereas the cover of all native plants was slightly higher. The cover of mosses did not change significantly, but in turn the cover of necromass decreased (Fig. $4 \mathrm{a}-\mathrm{c}$ ). The biodiversity indices as the mean number of species (Fig. 4d), mean value of Shannon-Wiener (Fig. 4e) and Simpson index (Fig. 4f) were higher in spring than in summer. Only evennes did not change significantly (Fig. 4g).

As shown, the total cover of Fallopia spp. had a negative impact on biodiversity, especially in summer. In spring Fallopia taxa only negatively influenced the number of species, but in summer they also affected the dominant species as well as the total cover of resident species (Tab. 3). Necromass in

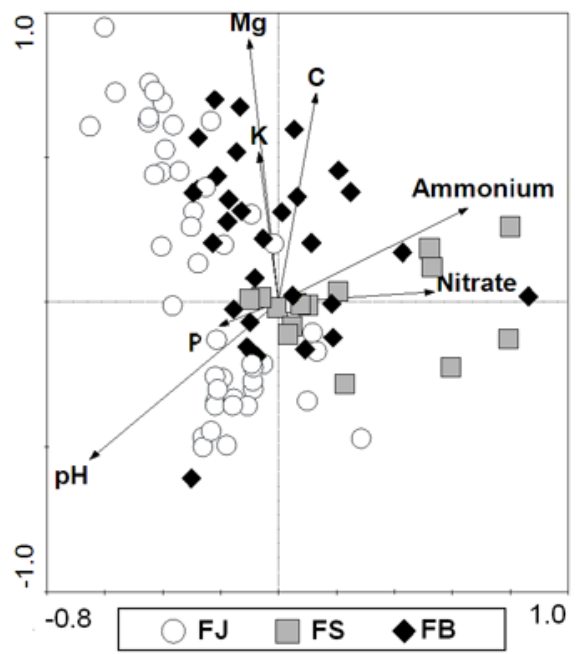

Fig. 2 Ordination of vegetation plots with Fallopia taxa and soils (data for spring) along the first two CCA axes $\left(\lambda_{1}=0.32, \lambda_{2}=0.28\right)$. The diagram accounts for $7.6 \%$ and $53.6 \%$ of variance of cover species data and fitted species data, respectively. FJ $-F$. japonica, FS - F. sachalinensis, FB - F. ×bohemica.

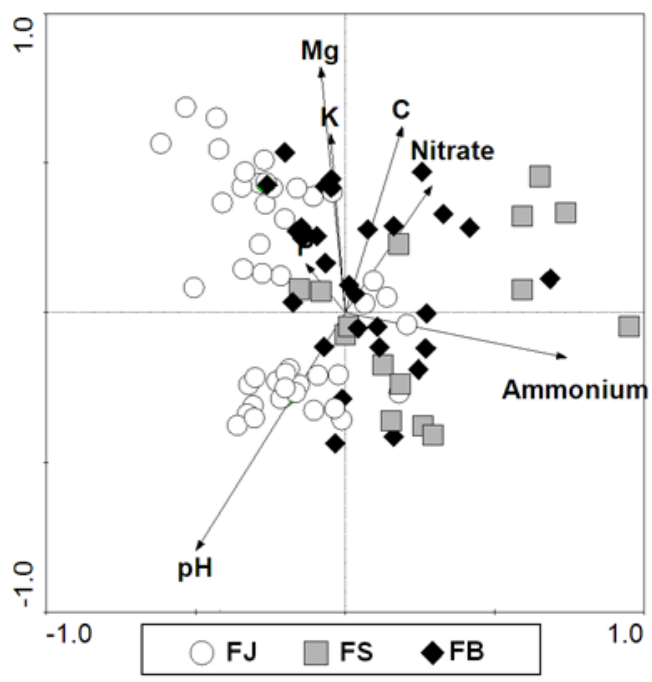

Fig. 3 Ordination of vegetation plots with Fallopia taxa and soils (data for summer) along the first two CCA axes $\left(\lambda_{1}=0.42, \lambda_{2}=0.25\right)$. The diagram accounts for $9.7 \%$ and $54.4 \%$ of variance of cover species data and fitted species data, respectively. FJ - F. japonica, FS - F. sachalinensis, FB - F. ×bohemica.

spring was negatively correlated, but in summer there was a positive relationship with the total cover of knotweeds. Analysis of vegetation patches dominated by particular taxa in both seasons demonstrated differences among knotweeds. Surprisingly the dominance of $F$. sachalinensis was positively correlated with species richness likewise with the ShannonWiener index and moss cover using the data for the whole year. Necromass, however, was negatively correlated with cover of $F$. sachalinensis both in spring and in summer. The data for spring and summer combined revealed negative 

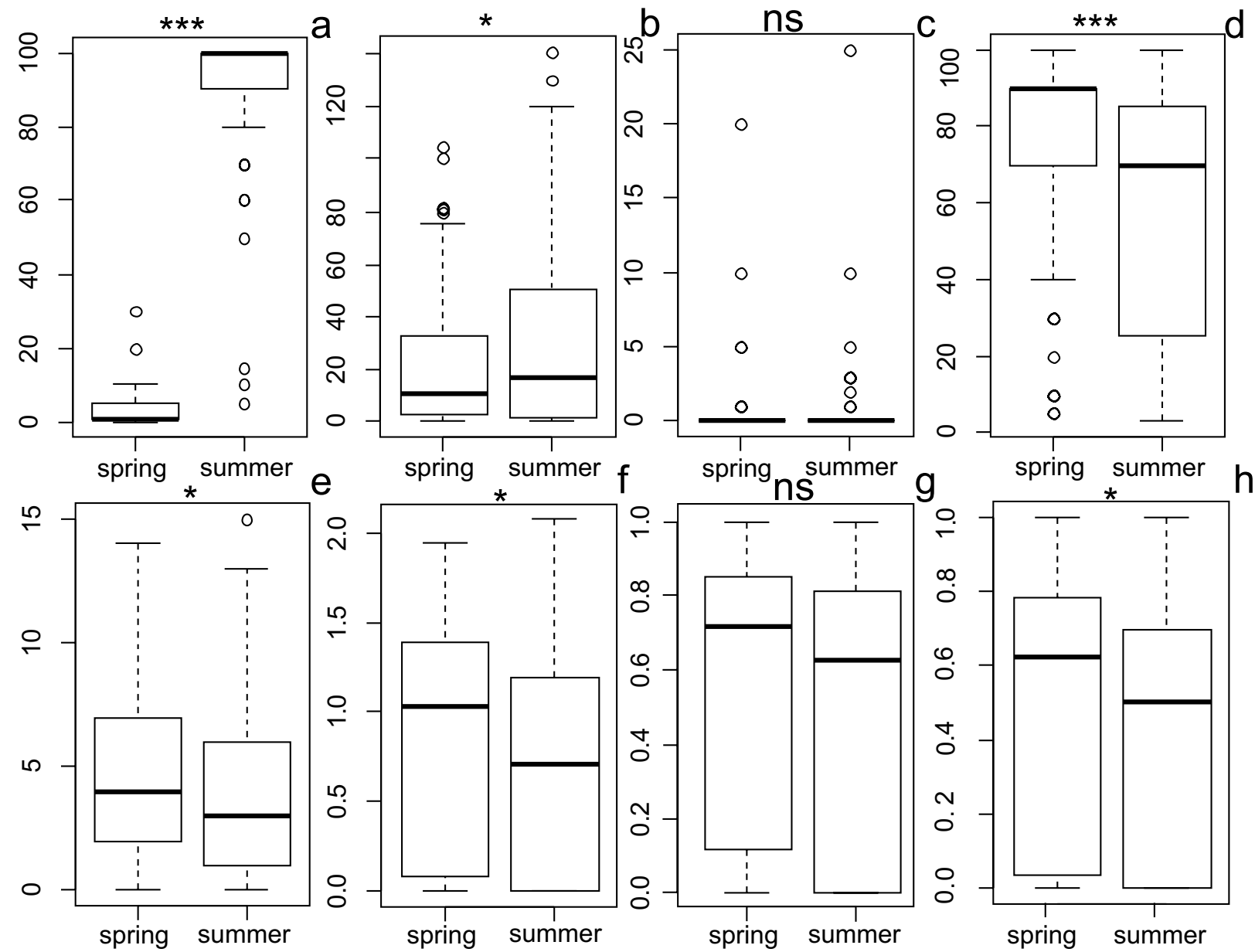

Fig. 4 Comparison of cover of Fallopia spp. (a), cover of native species (b), cover of mosses (c), cover of necromass (d), values of species richness (e), Shannon-Wiener (f), evenness (g), Simpson index (h) between spring and summer. ${ }^{\star} P<0.05$; ${ }^{* *} P<0.001$; ns - nonsignificant (Wilcoxon paired test).

Tab. 3 The Spearman rank correlation coefficients between cover of Fallopia taxa combined and particular Fallopia taxa and biodiversity indices, necromass and total cover of native species for spring and autumn and whole year combined.

\begin{tabular}{|c|c|c|c|c|c|c|c|c|c|c|c|c|}
\hline \multirow[b]{2}{*}{ Parameter } & \multicolumn{3}{|c|}{ Fallopia taxa combined } & \multicolumn{3}{|c|}{ F. japonica } & \multicolumn{3}{|c|}{ F. sachalinensis } & \multicolumn{3}{|c|}{ F. $\times$ bohemica } \\
\hline & Spring & Summer & Combined & Spring & Summer & Combined & Spring & Summer & Combined & Spring & Summer & Combined \\
\hline$H^{\prime}$ & ns & $-0.43^{* * *}$ & ns & ns & ns & ns & ns & ns & $0.21^{*}$ & ns & ns & $-0.21^{*}$ \\
\hline$D$ & ns & $-0.30^{* * *}$ & ns & ns & ns & ns & ns & ns & ns & ns & ns & $-0.29^{* *}$ \\
\hline E & ns & ns & ns & ns & ns & ns & ns & ns & ns & ns & ns & ns \\
\hline$s$ & $0.22^{*}$ & $-0.54^{* * *}$ & $-0.31^{* *}$ & ns & ns & ns & $\mathrm{ns}$ & ns & $0.22^{*}$ & ns & ns & $-0.27^{*}$ \\
\hline Moss cover & $0.25^{*}$ & ns & ns & ns & ns & ns & $0.48^{* * *}$ & $0.34^{* \star}$ & $0.34^{\star \star}$ & ns & ns & ns \\
\hline Necromass & $-0.44^{*}$ & $0.41^{* * *}$ & ns & $\mathrm{ns}$ & $0.31^{* * *}$ & 0.31 & $-0.51^{* * *}$ & $-0.34^{* *}$ & $-0.34^{* *}$ & ns & ns & ns \\
\hline $\begin{array}{l}\text { Total cover of } \\
\text { natives }\end{array}$ & ns & $-0.57^{* * *}$ & $-0.43^{* * *}$ & ns & $-0.35^{* * *}$ & -0.32 & $0.24^{*}$ & ns & ns & ns & ns & ns \\
\hline
\end{tabular}

${ }^{\star} P<0.05 ;{ }^{\star \star} P<0.01 ;{ }^{\star *} P<0.001 ;$ ns - non-significant. Bold values are significant after Bonferroni-Holm correction for multiple tests.

correlations between some biodiversity indices in patches dominated by the hybrid F. xbohemica. In turn Japanese Knotweed (F. japonica) cover was negatively correlated with total cover of native plants over the year and positively with necromass.
The Monte Carlo test showed that necromass had a significant correlation with species composition in spring, and the cover of mosses also significantly explained this variable (Tab. 4). A weak influence of $F$. x bohemica cover was also recorded (Fig. 5). In summer the situation changed. 
Tab. 4 The results of the Monte Carlo test ( $P$-values) in CCA with cover of Fallopia taxa, necromass and moss cover as constraining variables.

\begin{tabular}{lcc}
\hline Parameter & Spring & Summer \\
\hline Necromass & $\mathbf{0 . 0 0 1}$ & $\mathbf{0 . 0 0 1}$ \\
Moss cover & $\mathbf{0 . 0 4 6}$ & 0.387 \\
Fallopia $\times$ bohemica & $\mathbf{0 . 0 5 0}$ & $\mathbf{0 . 0 0 1}$ \\
Fallopia sachalinensis & 0.096 & $\mathbf{0 . 0 0 4}$ \\
Fallopia japonica & 0.690 & $\mathbf{0 . 0 4 4}$ \\
\hline
\end{tabular}

Bold values are significant at $P<0.05$.

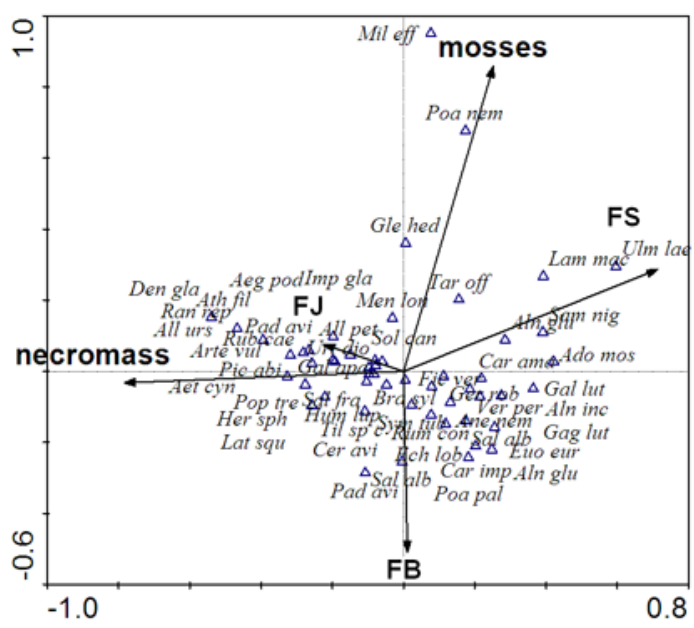

Fig. 5 Biplot of field layer species and Fallopia taxa (FJ, FS, FB), cover of mosses and necromass as predictor variables on the first two CCA axes $\left(\lambda_{1}=0.33, \lambda_{2}=0.27\right)$ in spring. The diagram accounts for $6.7 \%$ and $62.0 \%$ of variance of cover species data and fitted species data, respectively. The first three letters indicate the genus and species names, respectively.

In summer the species composition was mostly correlated with the presence of necromass, and the cover-abundance of all Fallopia taxa. Fallopia japonica affected the species composition less than the two other taxa. No influence of moss cover was recorded (Fig. 6).

Species which coexisted most frequently with particular Fallopia taxa, are listed in Tab. 5 and Tab. 6. With F. japonica, the most frequent species both in spring and summer were: Phalaris arundinacea L. and Agrostis capillaris L. whereas, only in spring, mainly Urtica dioica L. and Impatiens glandulifera Royle. Sites invaded by F. $\times$ bohemica were also sites of the occurrence of Populus tremula L. as trees and seedlings (Tab. 5, Tab. 6). Other frequent but not significantly associated species were: Poa palustris L., Cardamine impatiens L., and seedlings of Cerasus avium L.(Moench). The species which co-occurred with F. sachalinensis were Poa nemoralis L., Agrostis capillaris, Adoxa moschatellina L., Cardamine amara L.s.s., and trees of Alnus incana L. (Moench) and Ulmus laevis Pall. Some species, such as Alliaria petiolata
(M. Bieb.) Cavara \& Grande and Ficaria verna Huds. in spring, and Glechoma hederacea L. in summer, are equally confined both to F. japonica and F. sachalinensis stands. Trees of Salix alba L. were significantly more frequent in stands of F. sachalinensis and F. ×bohemica (Tab. 5, Tab. 6). No common associated species for both $F$. japonica and $F$. $\times$ bohemica sites were found. Some species, such as Aegopodium podagraria L. and Symphytum tuberosum L., were quite frequent in each type of plot. The cover of necromass affects similarly the cover of F. japonica in spring but in summer other species are associated with it, such as Calystegia sepium (L.) R. Br., Rubus caesius L., Aegopodium podagraria and Solidago canadensis L.

\section{Discussion}

\section{Environmental requirements of Fallopia taxa and} accompanying vascular plant species

In the present study we aimed, among other objectives, to examine soil variables diversity within habitats invaded by Fallopia taxa in two similar rivers. In contradiction to other studies (e.g. [36,37]), where selected sites were more variable, the results revealed that sites located along the two rivers hardly differed in the studied soil parameters. Thus, it can be inferred that the sites did not affect the results, and permitted analyses across the two rivers. Previous studies (e.g. [38-44]) demonstrated that in Poland the most frequently invaded habitats and the most favourable conditions (in terms of size of populations and morphometric traits) for species of Fallopia genus are riparian biotopes. It can be expected that the soil data obtained exhibited suitable conditions for particular Fallopia taxa. In our study it was revealed that $\mathrm{pH}$ in soils in the river valleys were estimated at ca. 6.5., whereas in wasteland in Belgium it varied between 4.9 to 7.4 [36]. Also Rahmonov et al. [45] showed that sites invaded by $F$. japonica are very diverse in $\mathrm{pH}$, from 4.0 to 7.5.

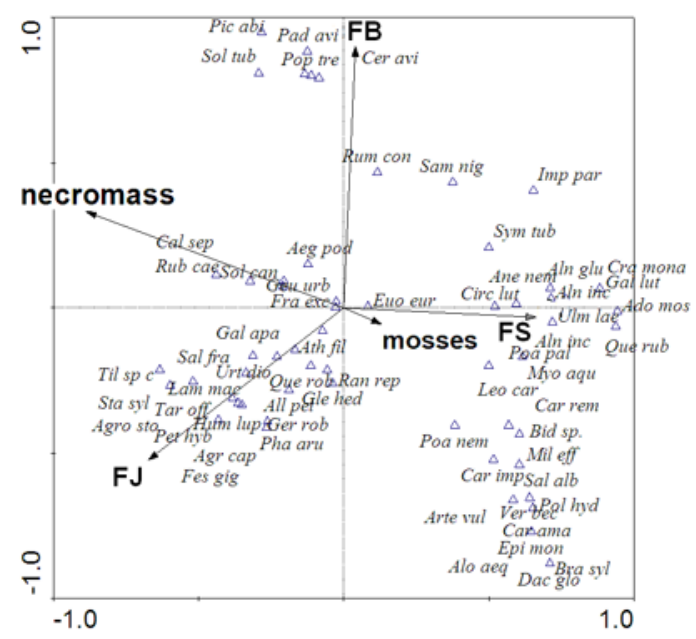

Fig. 6 Biplot of field layer species and Fallopia taxa, cover of mosses and necromass as predictor variables on the first two CCA axes $\left(\lambda_{1}=0.54, \lambda_{2}=0.43\right)$ in summer. The diagram accounts for $9.2 \%$ and $62.4 \%$ of variance of cover species data and fitted species data, respectively. The first three letters indicate the genus and species names, respectively. 
Tab. 5 The list of resident species significantly associated with groups of plots dominated by Fallopia taxa with value of IndVal, mean $\pm S D$ of cover and frequency (in parentheses) in spring.

\begin{tabular}{|c|c|c|c|c|c|}
\hline Taxon & IndVal & FJ & FS & FB & Freq \\
\hline \multicolumn{6}{|l|}{ Fallopia japonica } \\
\hline Urtica dioica & $0.528^{*}$ & $8.1 \pm 9.0(15)$ & $5(1)$ & $3.0 \pm 2.8(11)$ & (18) \\
\hline Phalaris arundinacea & $0.516^{* *}$ & $2.3 \pm 1.9(12)$ & - & - & (12) \\
\hline Agrostis capillaris & $0.471^{\star}$ & $1.8 \pm 1.7(10)$ & - & - & $(10)$ \\
\hline Impatiens glandulifera & 0.44 & $1.0 \pm 0.0(10)$ & - & - & (10) \\
\hline \multicolumn{6}{|l|}{ F. sachalinensis } \\
\hline Poa nemoralis & $0.632^{\star * *}$ & - & $3.2 \pm 3.7(6)$ & - & (6) \\
\hline Adoxa moschatellina & $0.577^{\star * *}$ & - & $5.2 \pm 3.2(5)$ & - & (5) \\
\hline Alnus incana $(\mathrm{A})$ & $0.566^{\star * *}$ & & $5.0 \pm 0.0(6)$ & $5.0 \pm 0.0(3)$ & (9) \\
\hline Gagea lutea & $0.544^{\star \star}$ & $1.0 \pm 0.0(2)$ & $2.6 \pm 2.2(5)$ & $1.0 \pm 0.0(2)$ & (9) \\
\hline Galeobdolon luteum & $0.447^{\star *}$ & - & $5.4 \pm 4.5(3)$ & - & (3) \\
\hline Ulmus laevis (A) & $0.447^{\star *}$ & - & $5.0 \pm 0.0(3)$ & - & (3) \\
\hline Milium effusum & $0.365^{\star}$ & - & $5.0 \pm 0.0(2)$ & - & (2) \\
\hline Veronica persica & $0.346^{*}$ & $1.0 \pm 0.0(2)$ & $3.0 \pm 2.8(5)$ & - & (7) \\
\hline \multicolumn{6}{|l|}{ F. $\times$ bohemica } \\
\hline Populus tremula (A) & $0.483^{\star *}$ & - & - & $4.4 \pm 2.8(7)$ & (7) \\
\hline \multicolumn{6}{|c|}{ F. japonica + F. sachalinensis } \\
\hline Ficaria verna & 0.76 & $5.8 \pm 10.8(28)$ & $26.6 \pm 20.4(10)$ & $4.8 \pm 5.7(13)$ & (51) \\
\hline Alliaria petiolata & $0.562^{*}$ & $1.0 \pm 0.0(18)$ & $1.0 \pm 0.0(3)$ & $1.0 \pm 0.0(2)$ & (23) \\
\hline \multicolumn{6}{|c|}{ F. sachalinensis + F. $\times$ bohemica } \\
\hline Salix alba (A) & $0.447^{\star}$ & $5.0 \pm 0.0(3)$ & - & $5.0 \pm 0.0(6)$ & (9) \\
\hline Total cover of native plants & & $16.7 \pm 21.0$ & $22.4 \pm 24$ & $41.5 \pm 35.6$ & \\
\hline
\end{tabular}

A - tree layer; C - herb layer. ${ }^{\star} P<0.05 ;{ }^{\star *} P<0.01 ;^{\star * \star} P<0.001$.

Tab. 6 The list of resident species significantly associated with groups of plots dominated by Fallopia taxa with value of IndVal, mean $\pm S D$ of cover and frequency (in parentheses) in summer.

\begin{tabular}{|c|c|c|c|c|c|}
\hline Taxon & IndVal & FJ & FS & FB & Freq \\
\hline \multicolumn{6}{|l|}{ Fallopia japonica } \\
\hline Agrostis capillaris & $0.447^{*}$ & $1.9 \pm 1.4(9)$ & - & - & (9) \\
\hline Phalaris arundinacea & $0.422^{*}$ & $8.5 \pm 9.6(8)$ & - & - & (8) \\
\hline \multicolumn{6}{|l|}{ F. sachalinensis } \\
\hline Alnus incana $\mathrm{A}$ & $0.49^{* *}$ & $15.0 \pm 0.0(6)$ & - & $40.0 \pm 0.0(9)$ & (15) \\
\hline Ulmus laevis A & $0.447^{\star *}$ & - & $15.0 \pm 0.0(3)$ & - & (3) \\
\hline Poa nemoralis & $0.43^{* *}$ & - & $1.4 \pm 0.6(3)$ & - & (3) \\
\hline Bidens sp. & $0.422^{*}$ & - & $1.3 \pm 0.6(3)$ & $1.0 \pm 0.0(1)$ & (4) \\
\hline Adoxa moschatellina & $0.365^{*}$ & - & $1.0 \pm 0.0(2)$ & - & (2) \\
\hline Cardamine amara & $0.365^{*}$ & - & $3.0 \pm 2.8(2)$ & - & (2) \\
\hline Galeobdolon luteum & $0.365^{*}$ & - & $10.0 \pm 7.0(2)$ & - & (2) \\
\hline Salix alba $\mathrm{C}$ & $0.365^{\star}$ & - & $1.0 \pm 0.0(2)$ & - & (2) \\
\hline Veronica beccabunga & $0.365^{\star}$ & - & $2.0 \pm 1.4(2)$ & - & (2) \\
\hline \multicolumn{6}{|l|}{ F. $\times$ bohemica } \\
\hline Populus tremula A & $0.483^{\star \star}$ & - & - & $25.0 \pm 15.3(7)$ & (7) \\
\hline Populus tremula C & $0.447^{\star \star}$ & - & - & $2.1 \pm 1.6(6)$ & (6) \\
\hline \multicolumn{6}{|c|}{ F. japonica + F. sachalinensis } \\
\hline Alliaria petiolata & $0.58^{*}$ & $5.8 \pm 5.2(17)$ & $4.0 \pm 2.0(4)$ & $1.0 \pm 0.0(4)$ & (25) \\
\hline Glechoma hederacea & $0.465^{\star}$ & $5.9 \pm 9.5(9)$ & $6.0 \pm 6.2(4)$ & - & (13) \\
\hline \multicolumn{6}{|c|}{ F. sachalinensis $+F . \times$ bohemica } \\
\hline Salix alba A & $0.447^{\star}$ & - & $15.0 \pm 0.0(3)$ & $15.0 \pm 0.0(6)$ & (9) \\
\hline Total cover of native plants & & $24.1 \pm 33.2$ & $26.3 \pm 20.6$ & $43.3 \pm 44.2$ & \\
\hline
\end{tabular}

A - tree layer; $\mathrm{C}$ - herb layer. ${ }^{*} P<0.05 ;{ }^{* *} P<0.01 ;{ }^{* *} P<0.001$. 
According to Beerling et al. [16] F. japonica can survive very harsh conditions with a $\mathrm{pH}$ range of 3.0-8.5. In our study the sites invaded by this species were more constrained by $\mathrm{pH}$ in CCA in comparison with $F . \times$ bohemica and $F$. sachalinensis. However, $\mathrm{pH}$ gradients arranged samples across F. japonica plots due to the high variation of species composition of accompanying plants. In spite of the fact that results are generally congruent they should be treated with caution because $\mathrm{pH}$ was studied by different methods in the cited studies. As regards nitrogen, in our study we focused on nitrate and ammonium ions, which are the available forms of this chemical element for plants, whereas in the majority of studies (e.g. [36,45]) total nitrogen was analyzed and did not exhibit differences among sites [45]. Sites with a higher content of the two forms of available nitrogen were more associated with $F$. $\times$ bohemica and, most of all, with F. sachalinensis but not with F. japonica, which partially confirms that the latter species can exist in areas with low available nitrogen [16]. With reference to the above, it can be stated that F. japonica is the most tolerant to high nitrogen variation in soil when compared to the remaining knotweed species. Concerning organic carbon, in our study soils were not very rich, as in the Belgium sites [36], but ours were more similar to the results obtained by Rahmonov et al. [45] for F. japonica. Furthermore, the concentration of phosphorus in our soils was very variable as in sites in Belgium [36]. The significance of the differences in plots scores (CCA) between the three types of plots showed not only slight differences in environmental requirements by knotweeds but, most of all, differences in the biotopic requirements of co-occurring plant species.

\section{Impact of Fallopia complex members on resident plant species}

As is well known, knotweeds plants grow markedly during the vegetation season. It has already been shown that from mid-April to June rapid longitudinal growth of stems, even as much as $40 \mathrm{~cm}$ per 4 days, takes place [20]. In the temperate conditions of Central Europe, all Fallopia taxa quickly build a dense leaf canopy from April to May [27]. Also Marigo and Pautou [46] claim that for Fallopia taxa, early seasonal development is typical. Taking into account the negative impact of these species on the co-occurring flora $[47,48]$ it could be expected that this impact would be much higher in summer when compared to spring. Indeed, Fallopia plants negatively influenced species richness and total cover of plants, but only in July. The negative relation between the cover of necromass at the beginning of the season and Fallopia cover, as well as the decrease in necromass in summer may be the result of the decomposition of fallen leaves during the vegetation season. Litter fall by Fallopia spp. (F. sachalinensis) was proven to cause a reduction in litter fall by native species, which was possible owing to a decrease in the cover of resident species [49]. Some studies concentrate on the litter decomposition rate in F. japonica [50] or chemical composition [49], but few studies focused on litter cover over time or its impact on resident species. It was already mentioned in general that the accumulation of leaf and stem litter, as well as a canopy that blocks light [16], are mechanisms which contribute to the displacement of native plants. We expected that the total cover of resident plants would be either lower or similar in summer as an effect of phenological changes and the influence of the knotweeds. However, a significant increase of their cover was observed. This demonstrates that the growth of all plants in the riparian habitat runs similarly, and competition among components of ground flora starts later. A higher number of species is associated with the increasing cover of Fallopia species in spring than is the case in summer. Thus, it can be concluded that the phenological aspect can bias interspecific interactions; however, in the peak of the vegetation season the impact of knotweeds is markedly negative. The possible mechanisms of impact are shading [27] and the allelopathic effect of phenolic compounds [14] which are released from leaf litter. The concentration of these compounds in soil solution is varied, but the effect of these substances is higher in early spring [51]. Shading, manifested by the high cover of the Fallopia canopy which was already mentioned, according to some sources may inhibit the germination of plants. In our case we observed a decrease in the cover of resident plants in the presence of the increasing cover of knotweeds. Our results suggest that the cover of Fallopia spp. mainly negatively affects the cover of resident vascular plants through shading and mechanical competition (overgrowing). As regards particular Fallopia taxa it turned out that only F. japonica and F. $\times$ bohemica exerted negative impact on total cover or species richness and the diversity of native plants. In case of F. sachalinensis positive relationship both for cumulative cover of all plants and species diversity of natives with increasing cover of this knotweed was observed. This result is in contrast to the findings of others, but it is worthy to mention that we did not compare invaded and uninvaded plots and made no comparison over time. Perhaps under canopy of F. sachalinensis some plant species are eliminated but others can benefit from the loss of the eliminated plants. The difference could arise from the fact that F. sachalinensis can have a system of growing underground rhizome distinct from that in the other two Fallopia taxa, without forming such compact crowns. Nevertheless, within F. sachalinensis stands, the cover of native plants is also rather low (Tab. 5). Even if the general pattern, based on literature data, show that F. sachalinensis has a negative impact on plants in riparian habitats, we have shown that sometimes in some sites the situation may be different. Positive correlation between giant knotweed and other species within vegetation dominated by this knotweed species does not have to indicate a positive role of this plant on biodiversity because only comparison with adjacent sites can answer this question. Moreover is worth considering the timing of the impact of the invasive plants on the conditions of habitat and the resident species. Presumably the residence time of Fallopia taxa in the river valleys examined is similar (certainly their occurrence en mass is confirmed for 15 years). The negative impact on resident riparian plants might be become detectable more rapidly in the case of F. japonica and F. $\times$ bohemica compared with F. sachalinensis. Nevertheless, it is apparent that the three Fallopia taxa influence the co-occurring plant composition in a different way or that the effect can be manifested at a different time in relation to the history of invasion. 


\section{Species diversity of particular Fallopia taxa patches}

Studies which are devoted to the relations between Fallopia spp. and resident plants species have not usually presented a complete list of accompanying species. However, sometimes there are brief references to the species richness of the coexisting flora. In our study we had a total of 54 resident species, including 46 native plants and 8 alien plants [neophytes: Echinocystis lobata (F. Michx.) Torr. \& A. Gray, Impatiens glandulifera, I. parviflora DC., Solidago canadensis, Quercus rubra L., Veronica persica Poir., Bidens frondosa L. and a cultivation escapee Solanum tuberosum L.] in 30 plots. This is a relatively small number of species, especially in habitats as species-rich as riparian zones. The previous study showed that totally 420 vascular plat species were found to occur in the section of the Sola river valley, 211 in Biała river valley and 160 in Jasienica stream valley [20]. In different types of habitats i.e. urban wastelands in 40 transects a total of 83 species were found [52]. This is a probably consequence of the relatively long residence time of knotweeds in the sites studied in the present investigation. According to Parepa et al. [30] in the initial phase of invasion, i.e. knotweed establishment, shading is the most crucial factor in the exclusion of resident species, but in later stages of invasion allelopathy might play a major role. That experimental study demonstrated that on average the biomass of native species was $20 \%$ lower than in plots without knotweeds, but most interesting was that $F . \times$ bohemica had the strongest impact on native plants. In our study in part we found significant differences among knotweeds in their impact on resident plants on the basis of value of correlations between cover of Fallopia taxa and the other plants (Tab. 3). Also, the lowest number of significantly associated species for $F . \times$ bohemica sites can in part confirm the observations of Parepa et al. [30]. As far as the resident species is concerned, some studies have shown that one of the most frequent accompanying species to Fallopia spp. is Urtica dioica $[16,20,22,52]$. It is a nitrophilous species, typical for riparian habitats. Others, such as Phalaris arundinacea, Agrostis capillaris were also reported by Barney et al. [53] and Beerling et al. [16] respectively. Some species which are commonly recorded as frequent associates e.g. Galium aparine L., Geranium robertianum L., Aegopodium podagraria $[16,22]$ were rare in the present study or did not have a preference for any of the Fallopia taxa. Bímová et al. [22] concluded that in Fallopia stands only three groups of plants are capable of coexisting with knotweeds: clonal ruderal plants, geophytes, and adult trees. Indeed, Urtica dioica belongs to the first group. Among the geophytes observed in this study, apart from the most frequent, such as Adoxa moschatellina L., Glechoma hederacea and the already mentioned $A$. podagraria and $P$. arundinacea, there were also: Calystegia sepium, Gagea lutea (L.) Ker Gawl., Allium ursinum L., Anemone nemorosa L., Circaea lutetiana L., Myosoton aquaticum (L.) Moench, Petasites hybridus (L.) Gaertn., B. Mey. \& Scherb. and Symphytum tuberosum L. These species were more frequently found in F. sachalinensis stands. Geophytes can survive due to a shift in phenology; they start the flowering phase before the rapid growth of the knotweeds, including F. sachalinensis, but this does not explain why geophytes are more frequent in giant knotweed stands. It is known that geophytes are less competitive than clonal ruderal plants and trees. One of the possible explanations could be a random distribution of plants, both knotweeds and resident species. Then negative or positive interspecific interactions would not be reflected. A second explanation could be a lower competition ability in F. sachalinensis or the already mentioned type of growth of this species. The leaves in this species are the largest in terms of leaf area among Fallopia spp. [36]. Thus, shading as a limiting factor ought to play the most significant role when compared with the remaining knotweeds. The most plausible explanation for the higher abundance of resident species is a lower ability for allelopathy in F. sachalinensis. On the other hand, other studies exhibited opposite patterns. For instance, Hejda et al. [34] demonstrated the greatest impact on species richness in the case of F. sachalinensis in comparison to F. japonica and F. $\times$ bohemica. It is unknown what effect particular knotweeds exert on all native species through allelopathy. One of species negatively affected by F. sachalinensis is Urtica dioica [14] which in this study is the least frequent in Giant knotweed stands. The third group mentioned by Bímová et al. [22] was trees. In our study some trees were found to co-occur with knotweeds, such as Populus alba, P. tremula, Salix alba, Ulmus laevis and Alnus incana. Poplars and willow were recorded as coexisting with $F$. $\times$ bohemica. Trees surely were without doubt present before the appearance of knotweeds in these sites, so we could rather state the relationship the other way round, i.e. that the occurrence of knotweeds is associated with the presence of trees. However we do not know the precise history of invasion by Fallopia spp. in this area. Nevertheless, it has already been shown that tree seedlings and small saplings can be outcompeted by Fallopia spp. [22]. Apart from Fallopia taxa a few invasive alien plant species were observed, such as Echinocystis lobata, Impatiens glandulifera, Solidago canadensis which are known to be quite frequent and abundant in riparian habitats in Central Europe $[6,40,54]$. The presence of these plants might be the result not only of similar biotopic requirements, but the consequence of invasion meltdown, i.e. mutual facilitation of invasion by a group of alien species. Kuebbing et al. [55] showed that there are still not many convincing, empirical studies supporting this concept. In our study, which revealed the frequent co-occurrence of knotweeds with some alien plant species, might be seen as shedding some light on this problem and requires further research.

\section{Conclusions}

We found differences in environmental conditions within one type of habitat - riparian zones - which is in contrast to other studies (e.g. [22]), where a wider array of habitats were investigated. These differences, which were obtained within vegetation patches containing knotweeds, in terms of environmental conditions and the species composition of coexisting plants, may be the consequence of two causes. The first cause may indicate various interspecific biotopic requirements, along the $\mathrm{pH}$ gradient, and in the content of nitrogen compounds in soil associated with the knotweed taxa. Thus, species associated with particular Fallopia taxa 
have similar habitat requirements. Alternatively, the second possible cause is that the knotweeds differ in their impact on resident species, which leads to differences in the species composition of the vegetation patches in which they dominate. Obviously, ecological drift sensu Hubbel [56] is also a possible factor explaining the differences in species composition in Fallopia spp. vegetation patches. This requires further detailed research. Knowledge of which native plants are more or less affected by particular knotweed taxa could

\section{Acknowledgments}

This project, No. NN 305384738, is financed by the Polish Ministry of Science and Higher Education. Special thanks to Jadwiga Derwisz, Agata Pawliczek, Tomasz Arendarczyk, Zenon Guzik, Sebastian Bzdęga, Jakub Guzik and Aleksander Woźniak for their help during the field work. We are grateful to two anonymous reviewers for their helpful comments. Ian C. Trueman (UK) kindly improved the English.

\section{Authors' contributions}

The following declarations about authors' contributions to the research have been made: design of the study: BTG, GW, KB, TN, DC; field research: BTG, TN, GW, KB, KK, MG, DC; analyzing data: DC; writing the manuscript: DC, BTG, GW, KB.

\section{Competing interests}

No competing interests have been declared.

\section{References}

1. Pyšek P, Kučera T, Jarošik V. Plant species richness of nature reserves: the interplay of area, climate and habitat in a Central European landscape. Glob Ecol Biogeogr. 2002;11:279-289. http://dx.doi. org/10.1046/j.1466-822X.2002.00288.x

2. Scalera R, Genovesi P, Essl F, Rabitsch W. The impacts of invasive alien species in Europe. EEA Technical report No. 16/2012.

3. Chytrý M, Maskell LC, Pino J, Pyšek P, Vilà M, Font X, et al. Habitat invasions by alien plants: a quantitative comparison among Mediterranean, subcontinental and oceanic regions of Europe. J Appl Ecol. 2008;45:448-458. http://dx.doi.org/10.1111/j.1365-2664.2007.01398.x

4. Sabo JL, Sponseller R, Dixon M, Gade K, Harms T, Heffernan J, et al. Riparian zones increase regional species richness by harboring different, not more, species. Ecology. 2005;86:56-62. http://dx.doi. org/10.1890/04-0668

5. Dajdok Z, Tokarska-Guzik B. Doliny rzeczne i wody stojące jako siedliska gatunków inwazyjnych. In: Dajdok Z, Pawlaczyk P, editors. Inwazyjne gatunki obce ekosystemów mokradłowych Polski. Świebodzin: Wydawnictwo Klubu Przyrodników; 2009. p. 24-31.

6. Pyšek P, Prach K. Plant invasions and the role of riparian habitats: a comparison of four species alien to Central Europe. J Biogeogr. 1993;20:413-420.

7. Planty-Tabacchi AM, Tabacchi E, Naiman RJ, Deferrari C, Decamps H. Invasibility of species-rich communities in riparian zones. Conserv Biol. 1996;10:598-607. http://dx.doi. org/10.1046/j.1523-1739.1996.10020598.x

8. Lowe S, Browne M, Boudjelas S, De Poorter M. 100 of the world's worst invasive alien species: a selection from the Global Invasive Species Database. Published by The Invasive Species Specialist Group (ISSG) a specialist group of the Species Survival Commission (SSC) of the World Conservation Union (IUCN) [Internet]. 2000 [cited 1 Feb 2013]. Available from: http://www.issg.org/database/species/ reference_files/100English.pdf

9. Seiger LA. The status of Fallopia japonica (Reynoutria japonica; Polygonum cuspidatum) in North America. In: Brock JH, Wade M, Pyšek P, Green D, editors. Plant invasions: studies from North America and Europe. Leiden: Backhuys Publishers; 1997. p. 95-102.

10. Bailey JP. Japanese knotweed s.l. at home and abroad. In: Child LE, be essential for nature conservation and management in river valleys. In any case, all Fallopia spp. have a negative impact on the species cover and species richness of resident plants, and this process is caused both by living plants and the necromass derived from the above ground biomass derived from the knotweeds. Moreover, it has been shown that the impact is intensified during the vegetation season and is strongest in summertime.

Brock JH, Brundu G, Prach K, Pyšek P, Wade PM, editors. Plant invasions: ecological threats and management solutions. Leiden: Backhuys Publishers; 2003. p. 183-196.

11. Gerber E, Krebs C, Murrell C, Moretti M, Rocklin R, Schaffner U. Exotic invasive knotweeds (Fallopia spp.) negatively affect native plant and invertebrate assemblages in European riparian habitats. Biol Conserv. 2008;141:646-654. http://dx.doi.org/10.1016/j.biocon.2007.12.009

12. Tokarska-Guzik B, Bzdęga K, Tarłowska S, Koszela K. Charakterystyka wybranych gatunków rozprzestrzeniających się na obszarach mokradłowych Polski. Rośliny nasienne. Rośliny wieloletnie. Gatunki z rodzaju rdestowiec Reynoutria (Fallopia). In: Z. Dajdok Z, Pawlaczyk P, editors. Inwazyjne gatunki obce ekosystemów mokradłowych Polski. Świebodzin: Wydawnictwo Klubu Przyrodników; 2009. p. 87-99.

13. Tokarska-Guzik B, Dajdok Z, Zając M, Zając A, Urbisz Al, Danielewicz W, et al. Rośliny obcego pochodzenia w Polsce ze szczególnym uwzględnieniem gatunków inwazyjnych. Warszawa: Generalna Dyrekcja Ochrony Środowiska; 2012.

14. Moravcová L, Pyšek P, Jarošík V, Zákravský P. Potential phytotoxic and shading effects of invasive Fallopia (Polygonaceae) taxa on the germination of dominant native species. NeoBiota. 2011;9:31-47. http://dx.doi.org/10.3897/neobiota.9.1266

15. Pyšek P, Brock JH, Bímová K, Mandák B, Jarošík V, Koukolíková I, et al. Vegetative regeneration in invasive Reynoutria (Polygonaceae) taxa: the determinant of invasibility at the genotype level. Am J Bot. 2003;90:1487-1495. http://dx.doi.org/10.3732/ajb.90.10.1487

16. Beerling DJ, Bailey JP, Conolly AP. Fallopia japonica (Houtt.) Ronse Decraene. J Ecol. 1994;82:959-979.

17. Child L, Wade M, Hathaway S. Strategic invasive plant management, linking policy and practice: a case study of Fallopia japonica in Swansea, South Wales (United Kingdom). In: Brundu G, Brock J, Camarda I, Child L, Wade M, editors. Plant invasions: species ecology and ecosystem management. Leiden: Bachuys Publishers; 2001 p. 291-302.

18. Richards CL, Walls RL, Bailey JP, Parameswaran R, George T, Pigliucci M. Plasticity in salt tolerance traits allows for invasion of novel habitat by Japanese knotweed s.l. (Fallopia japonica and F. bohemica, Polygonaceae). Am J Bot. 2008;95:931-942. http://dx.doi.org/10.3732/ ajb.2007364

19. Groeneveld E, Belizile F, Lavoie C. Sexual reproduction of Japanese knotweed (Fallopia japonica s.l.) at its northern distribution limit: new evidence of the effect of climate warming on an invasive species. Am J Bot. 2014;101(3):459-466. http://dx.doi.org/10.3732/ajb.1300386

20. Tokarska-Guzik B, Bzdęga K, Knapik D, Jenczała G. Changes in plant species richness in some riparian plant communities as a result of their colonisation by taxa of Reynoutria (Fallopia). Biodiv Res Conserv. 2006;1-2:123-130.

21. Lecerf A, Risnoveanu G, Popescu C, Gessner MO, Chauvet E. Decomposition of diverse litter mixtures in streams. Ecology. 2007;88: 219-22. http://dx.doi.org/10.1890/0012-9658(2007)88[219:DODLMI]2.0.CO;2

22. Bímová K, Mandák B, Kasparová I. How does Reynoutria invasion fit the various theories of invasibility? J Veg Sci. 2004;15:495-504. http:// dx.doi.org/10.1111/j.1654-1103.2004.tb02288.x

23. Dassonville N, Vanderhoeven S, Gruber W, Meerts P. Invasion by Fallopia japonica increases topsoil mineral nutrient concentration. Ecoscience. 2007;14:230-240. http://dx.doi. org/10.2980/1195-6860(2007)14[230:IBFJIT]2.0.CO;2 
24. Siemens TJ, Blossey B. An evaluation of mechanisms preventing growth and survival of two native species in invasive Bohemian knotweed (Fallopia $\times$ bohemica, Polygonaceae). Am J Bot. 2007;94(5):776783. http://dx.doi.org/10.3732/ajb.94.5.776

25. Csiszár Á, Korda M, Schmidt D, Šporcic D, Teleki B, Tiborcz V, et al. Study on allelopathic potential of some invasive and potentially invasive neophytes. International Scientific Conference March 26-27 2012 on Sustainable Development \& Ecological Footprint. Sopron: University of West Hungary; 2012. p. 1-6.

26. Balogh L. Japanese, giant and bohemian knotweed. In: Botta-Dukát $\mathrm{Z}$, Balogh L, editors. The most important invasive plants in Hungary. Vacratot: Institute of Ecology and Botany, Hungarian Academy of Sciences; 2008. p. 13-33.

27. Brabec J, Pyšek P. Establishment and survival of three invasive taxa of the genus Reynoutria (Polygonaceae) in mesic mown meadows: a field experimental study. Folia Geobot. 2000;35:27-42. http://dx.doi. org/10.1007/BF02803085

28. Bímová K, Mandák B, Pyšek P. Experimental study of vegetative regeneration in four invasive Reynoutria taxa (Polygonaceae). Plant Ecol. 2003;166(1):1-11. http://dx.doi.org/10.1023/A:1023299101998

29. Hollingsworth ML, Hollingsworth PM, Jenkins GI, Bailey JP, Ferris C. The use of molecular markers to study patterns of genotypic diversity in some invasive alien Fallopia spp. (Polygonaceae). Mol Ecol. 1998;7:1681-1691. http://dx.doi.org/10.1046/j.1365-294x.1998.00498.x

30. Parepa M, Fischer M, Krebs C, Bossdorf O. Hybridization increases invasive knotweed success. Evol Appl. 2014;7(3):413-420. http:// dx.doi.org/10.1111/eva.12139

31. Weber E, D'Antonio CM. Phenotypic plasticity in hybridizing Carpobrotus spp. (Aizoaceae) from coastal California and its role in plant invasion. Can J Bot. 1999;77:1411-1418. http://dx.doi.org/10.1139/ b99-091

32. Pyšek P, Richardson DM, Pergl J, Jarošík V, Sixtová Z, Weber E Geographical and taxonomic biases in invasion ecology. Trends Ecol Evol. 2008;23:237-244. http://dx.doi.org/10.1016/j.tree.2008.02.002

33. Bailey JP. The Japanese knotweed invasion viewed as a vast unintentional hybridisation experiment. Heredity. 2013;110(2):105-110. http://dx.doi.org/10.1038/hdy.2012.98

34. Hejda M, Pyšek P, Jarošík V. Impact of invasive plants on the species richness, diversity and composition of invaded communities. J Ecol. 2009;97(3):393-403. http://dx.doi. org/10.1111/j.1365-2745.2009.01480.x

35. de Cáceres MD, Legendre P, Moretti M. Improving indicator species analysis by combining groups of sites. Oikos. 2010;119(10):1674-1684. http://dx.doi.org/10.1111/j.1600-0706.2010.18334.x

36. Herpigny B, Dassonville N, Ghysels P, Mahy G, Meerts P. Variation of growth and functional traits of invasive knotweeds (Fallopia spp.) in Belgium. Plant Ecol. 2012;213(3):419-430. http://dx.doi.org/10.1007/ s11258-011-9989-9

37. Dassonville N, Vanderhoeven S, Vanparys V, Hayez M ,Gruber W, Meerts P. Impacts of alien invasive plants on soil nutrients are correlated with initial site conditions in NW Europe. Oecologia. 2008;157(1):131-140. http://dx.doi.org/10.1007/s00442-008-1054-6

38. Dajdok Z, Kącki Z. Kenophytes of the Odra riversides. In: Zając A, Zając M, Zemanek B, editors. Phytogeographical problems of synanthropic plants. Cracow: Institute of Botany, Jagiellonian University; 2003. p. 131-136.

39. Tokarska-Guzik B. Habitat preferences of some alien plants (kenophytes) occurring in Poland. In: Zając A, Zając M, Zemanek B, editors. Phytogeographical problems of synanthropic plants. Cracow: Institute of Botany, Jagiellonian University; 2003. p. 75-83.

40. Tokarska-Guzik B. Invasive ability of kenophytes occurring in Poland: a tentative assessment. In: Nentwig W, Bacher S, Cock MJW, Dietz H,
Gigon A, Wittenberg R, editors. Biological invasions from ecology to control. 2005. p. 47-65. (NeoBiota; vol 6).

41. Koszela K, Tokarska-Guzik B. Alien plant species in the protection landscape area of the Odra river meanders: habitat preferences and threat. Biodiv Res Conserv. 2008;1-2:73-80.

42. Uziębło A, Skowronek I. Penetration of anthropophytes into alluvial phytocoenoses of the Skawica river valley (western Carpathians). Biodiv Res Conserv. 2008;9-10:43-50.

43. Zajac A, Tokarska-Guzik B, Zajac M. The role of rivers and streams in the migration of alien plants into the Polish Carpathians. Biodiv Res Conserv. 2011;23:43-56.

44. Chmura D, Nejfeld P, Borowska M, Woźniak G, Nowak T, TokarskaGuzik B. The importance of land use type in Fallopia (Reynoutria) japonica invasion in the suburban environment. Pol J Ecol. 2013;61(2):379-384.

45. Rahmonov O, Czylok A, Orczewska A, Majgier L, Parusel T. Chemical composition of the leaves of Reynoutria japonica Houtt. and soil features in polluted areas. Cent Eur J Biol. 2014;9(3):320-330. http:// dx.doi.org/10.2478/s11535-013-0267-9

46. Marigo G, Pautou G. Phenology, growth and ecophysiological characteristics of Fallopia sachalinensis. J Veg Sci. 1998;9:379-386. http:// dx.doi.org/10.2307/3237102

47. Aguilera AG, Alpert P, Dukes JS, Harrington R. Impacts of the invasive plant Fallopia japonica (Houtt.) on plant communities and ecosystem processes. Biol Invasions. 2012;12:1243-1252. http://dx.doi. org/10.1007/s10530-009-9543-Z

48. Murrell C, Gerber E, Krebs C, Parepa M, Schaffner U, Bossdorf O. Invasive knotweed affects native plants through allelopathy. Am J Bot. 2011;98(1):38-43. http://dx.doi.org/10.3732/ajb.1000135

49. Urgenson LS, Reichard SH, Halpern CB. Community and ecosystem consequences of giant knotweed (Polygonum sachalinense) invasion into riparian forests of western Washington, USA. Biol Conserv. 2009;142(7):1536-1541. http://dx.doi.org/10.1016/j. biocon.2009.02.023

50. Mincheva T, Barni E, Varese GC, Brusa G, Cerabolini B, Siniscalco C. Litter quality, decomposition rates and saprotrophic mycoflora in Fallopia japonica (Houtt.) Ronse Decraene and in adjacent native grassland vegetation. Acta Oecol. 2014;54:29-35. http://dx.doi. org/10.1016/j.actao.2013.03.010

51. Lohdi MAK. Soilplant phytotoxicity and its possible significance in patterning of herbaceous vegetation in a bottomland forest. Am J Bot. 1975;62:618-622. http://dx.doi.org/10.2307/2441940

52. Maurel N, Salmon S, Ponge JF, Machon N, Moret J, Muratet A. Does the invasive species Reynoutria japonica have an impact on soil and flora in urban wastelands? Biol Invasions. 2010;12(6):1709-1719. http://dx.doi.org/10.1007/s10530-009-9583-4

53. Barney JN, Tharayil N, DiTommaso A, Bhowmik PC. The biology of invasive alien plants in Canada. 5. Polygonum cuspidatum Sieb. \& Zucc. [=Fallopia japonica (Houtt.) Ronse Decr.]. Can J Plant Sci. 2006;86:887-905. http://dx.doi.org/10.4141/P05-170

54. Kopeć D, Ratajczyk N, Wolańska-Kamińska A, Walisch M, Kruk A. Floodplain forest vegetation response to hydroengineering and climatic pressure - a five decade comparative analysis in the Bzura River valley (central Poland). For Ecol Manage. 2014;314:120-130. http://dx.doi.org/10.1016/j.foreco.2013.11.033

55. Kuebbing SE, Nuñez MA, Simberloff D. Current mismatch between research and conservation efforts: The need to study co-occurring invasive plant species. Biol Conserv. 2013;160:121-129. http://dx.doi. org/10.1016/j.biocon.2013.01.009

56. Hubbell SP. The unified neutral theory of biodiversity and biogeography. Princeton, NJ: Princeton University Press; 2001. 